
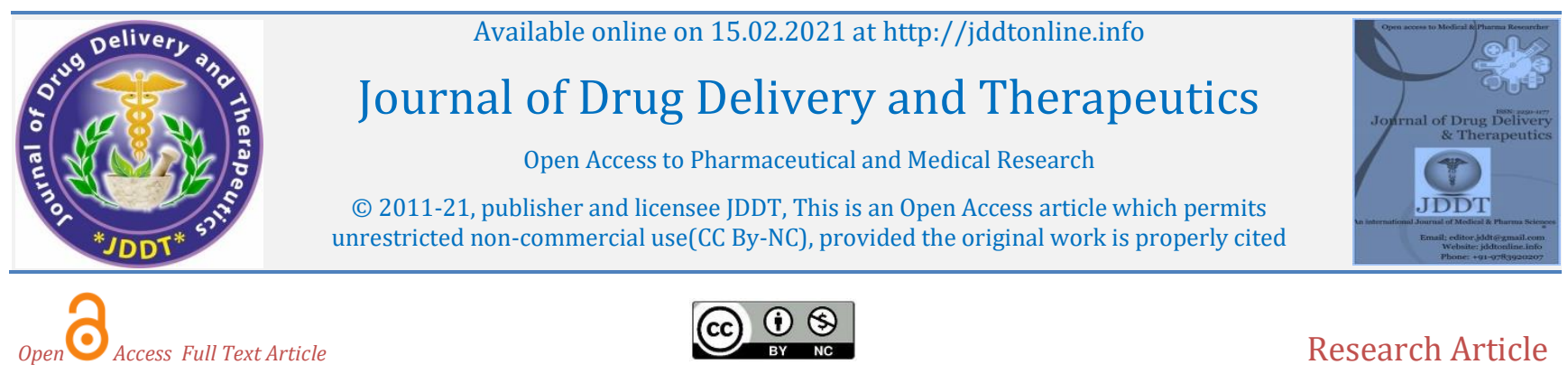

Research Article

\title{
Muco-adhesive buccal tablets of candesartan cilexetil for oral delivery: preparation, in-vitro and ex-vivo evaluation
}

\author{
Kumara Swamy Samanthula1*, Agaiah Goud Bairi², Mahendra Kumar CB³ \\ ${ }^{1}$ Vaagdevi Pharmacy College, Bollikunta, Warangal, Telangana, India \\ ${ }^{2}$ S.R.R College of Pharmaceutical Sciences, Valbhapur, Warangal, Telangana, India \\ ${ }^{3}$ St. Mary's College of Pharmacy, Secunderabad, Telangana, India
}

Article Info:

Article History:

Received 11 Dec 2020;

Review Completed 18 Jan 2021

Accepted 26 Jan 2021;

Available online 15 Feb 2021

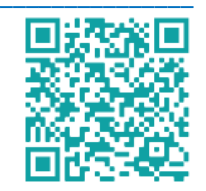

Cite this article as:

Samanthula KS, Bairi AG, Mahendra Kumar CB, Mucoadhesive buccal tablets of candesartan cilexetil for oral delivery: preparation, in-vitro and ex-vivo evaluation, Journal of Drug Delivery and Therapeutics. 2021; 11(1s):35-42

DOI: http://dx.doi.org/10.22270/jddt.v11i1-s.4547

\section{*Address for Correspondence:}

Kumara Swamy Samanthula, Vaagdevi Pharmacy College, Bollikunta, Warangal, Telangana, India

\section{Abstract}

Candesartan cilexetil (CC) is an angiotensin II-receptor blocker (ARB). The antihypertensive effect of CC $4-16 \mathrm{mg} /$ day was as great as that of other once-daily dosage regimens. Candesartan cilexetil has high first-pass metabolism and low oral bioavailability. The bioavailability of such drugs may be significantly improved if delivered through the buccal route; hence mucosal delivery is one of the alternative methods of systemic drug delivery. This study's objective was to develop mucoadhesive buccal tablets of candesartan cilexetil using carbopol-934P, hydroxyl propyl methyl cellulose (HPMC), Eudragit RLPO, and sodium carboxy methyl cellulose (Na-CMC) as mucoadhesive polymers. Prepared CC buccal tablet formulations were evaluated for an optimized system based on physicochemical properties, ex-vivo residence time, in-vitro, and ex vivo permeation studies. The evaluation parameters of the tablets were within the acceptable Pharmacopoeial limits. However, the swelling and bio-adhesive time were increased with increasing polymer concentrations. The in-vitro release research shown that buccal tablets with sodium carboxy methyl cellulose (Na-CMC) exhibited a higher release than all other formulations and have been considered as optimized CC formulation. The release mechanism from kinetic methods suggests that the drug release follows zero-order kinetics with a diffusion mechanism. Further, in-vivo research in animal fashions is required to prove the bioavailability performance of the formulation.

Keywords: Candesartan cilexetil, mucoadhesive buccal tablets, first-pass metabolism, bioavailability.

\section{INTRODUCTION:}

In the past three decades, there is a splendid interest in researching buccal drug transport systems. The oral cavity is effortlessly acceptable for self-medication of drugs and is nicely popular among patients ${ }^{1}$. The oral cavity space is the most appealing path for drug transport due to its ease of management. This path may administer each locally performing and appearing systemic drugs. The mucosa drug's site-precise release is accomplished while used for local activity, and systemic action expects for drug absorption through the mucosal barrier to reach systemic flow $^{2}$. The oral route is the maximum favored and widely relevant direction for delivering the majority of the medicine.

However, problems such as less residence time, poor aqueous solubility, and chemical instability in the gastrointestinal tract minimize orally administered medicines' bioavailability ${ }^{3}$. Further, metabolism through diverse obstacles or enzymes also degrades the drug earlier than attaining the site of action. The buccal mucosa has been investigated for therapeutic agents subjected to first bypass metabolism and risky inside the rest of the gastrointestinal tract ${ }^{4,5}$. The mucosal lining of the oral cavity and nasal cavity gives a few excellent benefits 6 . It has primarily vascularized, and buccal drug transport has high patient acceptability. Hence, diverse alternative drug delivery systems are evolved to enhance the oral bioavailability of those medicines.

Oral mucosal drug delivery is one of the alternative systemic drug absorption strategies that offer decorate drug bioavailability 7,8 . The bioavailability of such medicines can be considerably progressed if added through a buccal pathway. Recently much attention has been focused on the design, development, and evaluation of buccal drug transport systems preserving in view their potential for the future market ${ }^{9,10}$.

Candesartan cilexetil (CC) is selective angiotensin (AT) type1 receptor antagonist used in the treatment of high blood pressure and congestive heart failure. It selectively blocks the binding of angiotensin II to AT1 in the majority of the wall of blood vessels tissues like vascular smooth muscle and the adrenal glands ${ }^{11}$. It inhibits the AT 1-mediated vasoconstrictive and aldosterone-secreting consequences of angiotensin II and consequences in an overall decrease in blood pressure ${ }^{12}$. However, its broad first-pass metabolism results in poor bioavailability i.e. $\approx 15 \%$. It has a plasma halflife of nine hours and peak plasma concentration reaches within three to four hours. It can be given once or twice day 
by day with a complete everyday dose ranging from $8 \mathrm{mg}$ to $32 \mathrm{mg}$ for the treatment of high blood pressure and heart failure ${ }^{13,14}$. It was selected as a model drug for this research due to its appropriate properties.

The present research's main objective was to design, develop the formulation, and evaluate mucoadhesive buccal tablets of CC (CC-BT) to improve oral bioavailability. Accordingly, CCBT was developed and evaluated for an optimized system based on various parameters it includes in vitro dissolution and permeation studies through the porcine membrane.

\section{MATERIALS AND METHODS:}

Candesartan cilexetil was obtained as a gift sample from Dr. Reddy's labs, Hyderabad India. Carbopol 934P was obtained from S.D. Fine Chemicals, Mumbai. Hydroxy propyl methyl cellulose (HPMC K4M), Eudragit RLPO and sodium carboxy methyl cellulose (Na-CMC) was obtained from Loba chemicals, Mumbai. All other ingredients used in formulations were of analytical grade.

\section{Preparation of mucoadhesive buccal tablets:}

Buccal muco-adhesive tablets were prepared by direct compression technique using a variable concentration of carbopol 934P, HPMC K4M, Eudragit RLPO, and sodium carboxy methyl cellulose (Na-CMC) ${ }^{15}, 16$. The drug, respective polymer, and MCC have weighed accurately and then passed thru sieve no. 80 to get uniform particle size. Then all of the substances besides lubricants and glidants have been combined with the aid of triturating for 10 to $15 \mathrm{~min}$ in a mortar with a pestle to achieve a uniform mixture. Subsequently, magnesium stearate and talc have been added. The combined powder turned compressed into tablets weighing $150 \mathrm{mg}$ the usage of a tablet device having a flatfaced punch and die set of $8 \mathrm{~mm}$ diameter (Rimek Minipress Karnavati Engg. Ltd, Ahmadabad, India). The compositions of the tablets were shown in Table 1.

Table 1: Formulation composition of mucoadhesive tablets of candesartan cilexetil

\begin{tabular}{|c|c|c|c|c|c|c|c|c|c|}
\hline Ingredients (mg) & F1 & F2 & F3 & F4 & F5 & F6 & F7 & F8 & F9 \\
\hline Candesartan cilexetil (CC) & 16 & 16 & 16 & 16 & 16 & 16 & 16 & 16 & 16 \\
\hline Carbopol 934P & 15 & 15 & 15 & 15 & 15 & 15 & 15 & 15 & 15 \\
\hline HPMC K4M & 30 & 45 & 60 & - & - & - & - & - & - \\
\hline Eudragit RLP0 & - & - & - & 30 & 45 & 60 & - & - & - \\
\hline Na CMC & - & - & - & - & - & - & 30 & 45 & 60 \\
\hline MCC & 84 & 69 & 54 & 84 & 69 & 54 & 84 & 69 & 54 \\
\hline Talc & 2 & 2 & 2 & 2 & 2 & 2 & 2 & 2 & 2 \\
\hline Mg Stearate & 2 & 2 & 2 & 2 & 2 & 2 & 2 & 2 & 2 \\
\hline Aspertame & 1 & 1 & 1 & 1 & 1 & 1 & 1 & 1 & 1 \\
\hline Total weight (mg) & 150 & 150 & 150 & 150 & 150 & 150 & 150 & 150 & 150 \\
\hline
\end{tabular}

\section{Evaluation of muco-adhesive buccal tablets}

\section{Hardness and thickness:}

Hardness is an essential quality control check to be indicated for measuring the capacity of a tablet to withstand mechanical shocks while managing. The test was carried out for three tablets from each formulation using the Monsanto hardness tester; the expected mean and standard deviation values were calculated ${ }^{17}$.

The thickness of randomly selected three mucoadhesive buccal tablets turned into determined with the assist of vernier calipers. Individual tablets from every formulation have been chosen, and the mean results were noted ${ }^{18}$.

\section{Weight variation and friability:}

Weight variation was performed for randomly selected 20 tablets from each batch using an electronic balance, and mean values were calculated. The percentage difference in the weight variation should be within the permissible limits and shown in the below Table 2 as per the USP19,20.

Friability is a measure of the mechanical strength of tablets. By using Roche friabilator, a sample of pre-weighed tablets were placed in the plastic chamber then operated for 100 revolutions ( $4 \mathrm{~min}$ and $25 \mathrm{rpm}$ ), every rotation tablet was dropped 6 inches distance, tablets have been reweighed; loss within the weight of the tablet is the measure of friability ${ }^{21}$ and is expressed in percent as:

$$
\mathrm{F}(\%)=\left[1-\mathrm{W}_{\mathrm{F}} / \mathrm{Wo}\right] \times 100
$$

Where, Wo is the weight of the tablets before the test and $\mathrm{W}_{\mathrm{F}}$ is the weight of the tablets after test

Table 2: Percentage difference allowed for weight variation

\begin{tabular}{|c|c|c|}
\hline S.No & $\begin{array}{c}\text { Average Weight of the } \\
\text { tablets in milligram }\end{array}$ & $\begin{array}{c}\text { Maximum percentage } \\
\text { difference allowed }\end{array}$ \\
\hline 1 & 130 or less & \pm 10 \\
\hline 2 & $130-324$ & \pm 7.5 \\
\hline 3 & More than 324 & \pm 5 \\
\hline
\end{tabular}

\section{Drug content:}

Randomly selected ten tablets from each formulation were crushed and get a fine powder from the mixture, one tablet equivalent of the mixture dissolved in $\mathrm{pH} 6.8$ phosphate buffer $22-24$. The amount of drug present in the mixture was analyzed using UV-Visible spectrophotometer at $256 \mathrm{~nm}$. 


\section{Swelling studies of buccal tablets:}

A mucoadhesive buccal adhesive system's swelling behavior is an important property for uniform and prolonged release of drug and bio-adhesiveness ${ }^{25,26}$. The swelling properties and the tablets' erosion characteristics were determined by the percentage of hydration and matrix erosion or dissolution. The percentage values were calculated according to the following equations:

Swelling Index $=\left[\left(\mathrm{W}_{2}-\mathrm{W}_{1}\right) \div \mathrm{W}_{1}\right] \times 100$

Where, $\quad W_{1}=$ initial weight of the tablet

$\mathrm{W}_{2}$ = final weight of the swollen tablet

\section{In-vitro drug release studies:}

A cyanoacrylate adhesive impermeable backing membrane was placed on one side of the tablet, and a piece of glass slide was fixed as support of the tablet to prevent the dosage form from floating. Then it was placed in USP type II (Electro lab, Mumbai, India) dissolution apparatus containing $500 \mathrm{~mL}$ of pH 6.8 phosphate buffer, maintained a temperature of $37 \pm$ $0.5^{\circ} \mathrm{C}$, and the apparatus run at a speed of $50 \mathrm{rpm}^{27}$. Samples were collected at preset time points and analyzed using a UV-Visible spectrophotometer at $256 \mathrm{~nm}$.

\section{Ex-vivo mucoadhesive residence time:}

The ex-vivo residence time is one of the significant parameters of the buccal mucoadhesive tablet ${ }^{28}$. It was determined using a USP dissolution apparatus, and the medium was composed of $500 \mathrm{~mL} \mathrm{pH} 6.8$ phosphate buffer maintained at $37^{\circ} \mathrm{C} \pm 0.5^{\circ} \mathrm{C}$. The porcine buccal tissue was glued to a glass slab's surface, vertically attached to the apparatus. The mucoadhesive tablet was pressed over excised, glued pig mucosa for 30 seconds, and immersed in a basket. The paddle apparatus rotated at $25 \mathrm{rpm}$, and the time required for complete erosion or detachment from the mucosa was recorded.

\section{Ex vivo permeation of buccal tablets:}

The porcine buccal mucosa was collected from the local slaughterhouse, and a drug permeation study was performed using a Franz diffusion cell at $37^{\circ} \mathrm{C} \pm 0.5^{\circ} \mathrm{C}^{29}$. The buccal mucosa was fixed between the donor and receptor compartments. pH 6.8 phosphate buffer filled in the receptor chamber, and the tablet was placed in the donor chamber with a few $\mathrm{ml}$ of the same buffer added for wetting of tablet. The receiving compartment's hydrodynamics was maintained by continuous stirring with a magnetic bead at a uniform speed throughout the study. Samples were collected at preset time intervals, and the amount of drug permeated through the buccal mucosa was then determined by using UV spectrophotometer at $256 \mathrm{~nm}$. The amount permeated and flux was calculated as per previously reported methods ${ }^{30,31}$.

The experiments were performed in triplicate $(n=3)$ and mean value was used to calculate the flux (J), permeability coefficient $(\mathrm{P})$

$$
\begin{aligned}
& J=\frac{(d Q / d t)}{A} \\
& P=\frac{(d Q / d t)}{\Delta C A}
\end{aligned}
$$

Where, J is the steady-state flux (mg.hrs $\left.{ }^{-1} \mathrm{~cm}^{-2}\right)$

$\mathrm{P}$ is permeability coefficient $(\mathrm{cm} / \mathrm{h})$
$\Delta \mathrm{C}$ is the concentration difference across the mucosa and A the area of diffusion $\left(\mathrm{cm}^{2}\right)$.

\section{Dissolution data kinetic analysis:}

Inside the order of describing the kinetics of drug release the process of drug release in specific type formulations, models have been fitting to the dissolution data of all formulations for linear regression analysis ${ }^{32}$.

\section{Zero order release kinetics:}

$$
\mathrm{Qt}=\text { Qo-Kot }
$$

$\mathrm{Q} t=$ amount of drug dissolved in time $\mathrm{t}$,

$\mathrm{Qo}=$ initial amount of drug

Ko=is zero order release rate constant

\section{First order release kinetics:}

This model's application to drug dissolution studies used to choose to describe absorption elimination of the drugs. To study $1^{\text {st }}$ order release rate kinetics, the release rate data were fitted to the below equation.

$$
\log Q t=\log Q 0+K_{1} t / 2.303
$$

$\mathrm{Qt}=$ amount of drug released time $\mathrm{t}$,

Qo= initial amount of drug

$\mathrm{K}_{1}=$ is the first-order release rate constant

\section{Higuchi model:}

Theoretical models of Higuchi developed for the study of drug release of water soluble and low soluble drugs incorporated in semi-solid and/or solid matrixes. Mathematical expressions obtained for drug release particles were dispersed in the uniformed matrix system behaving as diffusion media. The equation is

$$
\begin{aligned}
& \qquad Q_{t}=K_{H} \cdot t^{1} / 2 \\
& Q_{t}=\text { amount of drug released in the time } t, \\
& K_{H}=\text { is Higuchi dissolution constant }
\end{aligned}
$$

Higuchi model explains the release as the diffusion process based on the Ficks law, square root time dependent.

\section{Korsmeyer and Peppas model:}

This model can be generally used to analyze the release of pharmaceutical polymeric dosage forms, when the release mechanism is not well known or when > one type of release phenomenon could be involved.

$$
\mathrm{Mt} / \mathrm{M}=\mathrm{K} . \mathrm{t}_{\mathrm{n}}
$$

$\mathrm{Mt} / \mathrm{M}$-- the fraction amount drug release

$\mathrm{n}$ is the diffusion exponent for the release and it depends on that shape of the matrix dosage form. If $n<0.45$, Fickian diffusion mediated drug release occurs. Non- Fickian release occurs if $0.45<\mathrm{n}<0.89$ and erosion (i.e. complete matrix relaxation) mediated release occurs in $n=0.89$.

\section{FTIR compatibility studies:}

FT-IR spectrophotometer was used to find the possible chemical interaction of CC with polymers and other excipients. The samples were prepared for FTIR test, as pure drug and as a drug with those polymers in 1:1 ratios. 


\section{RESULTS AND DISCUSSION}

CC has poor oral bioavailability due to poor aqueous solubility and first-pass metabolism. Hence, there is a need to develop alternative delivery system for enhanced oral delivery either through enhanced water solubility or avoiding first-pass metabolism. Previously, various nano delivery systems of CC has been reported to enhance oral bioavailability33-35. But, in the present investigation buccal delivery system has been developed for enhancement of oral bioavailability.

Various alternative drug delivery systems are developed to enhance the oral bioavailability of poorly soluble drugs. The delivery systems include; enhancement of solubility through solid dispersions ${ }^{36,37}$, liquisolid compact ${ }^{38}$, increase the stability and prolonged residence time through floating systems ${ }^{39}$, lipid-based delivery systems for by passing metabolism with solid lipid nanoparticles ${ }^{40-44}$, SMEDDS 45 , transfersomes ${ }^{46}$, nanostructured lipid carriers $^{47}$ and micronization for reducing particle size using nanosuspensions ${ }^{48,49}$.

\section{Physical parameters muco-adhesive buccal tablets:}

The physicochemical properties of all the formulations prepared with different were described in earlier sections and evaluated to various tests. The tests viz., hardness, thickness, weight variation, and drug content were found to be within the pharmacopeia limits and are given in the Table 3. The hardness of the tablets ranged $3.95 \pm 1.25$ to $4.65 \pm 1.63$ $\mathrm{kg} / \mathrm{cm}^{2}$ and the thickness of the tablets ranged from $2.58 \pm 0.13$ to $2.65 \pm 0.66 \mathrm{~mm}$. The uniformity of weight as their weights varied between $148.6 \pm 0.41$ and $2.59 \pm 0.16 \mathrm{mg}$ and the friability values were less than $1 \%$. All the formulations were satisfied with the content of the drug as they contained $2.59 \pm 0.16$ to $100.12 \pm 2.55 \%$. Thus all the physical properties of the prepared tablets were found to be pragmatically within the pharmacopeia limits.

Table 3: Physical evaluation parameters of CC buccal tablets

\begin{tabular}{|c|c|c|c|c|c|}
\hline Formulation & Hardness (Kg/cm $\mathbf{c}^{\mathbf{}}$ ) & Thickness (mm) & Weight Variation (mg) & Friability (\%) & Drug content (\%) \\
\hline F1 & $3.98 \pm 1.53$ & $2.58 \pm 0.13$ & $151 \pm 1.95$ & $0.65 \pm 0.12$ & $99.68 \pm 2.33$ \\
\hline F2 & $4.12 \pm 1.25$ & $2.59 \pm 0.15$ & $149 \pm 1.63$ & $0.53 \pm 0.13$ & $99.46 \pm 2.69$ \\
\hline F3 & $4.25 \pm 1.66$ & $2.58 \pm 0.13$ & $152 \pm 1.69$ & $0.56 \pm 0.15$ & $98.63 \pm 1.96$ \\
\hline F4 & $4.18 \pm 1.26$ & $2.59 \pm 0.15$ & $151 \pm 1.93$ & $0.49 \pm 0.15$ & $100.12 \pm 2.55$ \\
\hline F5 & $4.29 \pm 1.45$ & $2.58 \pm 0.13$ & $149 \pm 1.33$ & $0.53 \pm 0.16$ & $98.47 \pm 1.75$ \\
\hline F6 & $4.65 \pm 1.63$ & $2.59 \pm 0.16$ & $152 \pm 1.48$ & $0.46 \pm 0.15$ & $99.66 \pm 166$ \\
\hline F7 & $3.95 \pm 1.25$ & $2.58 \pm 0.16$ & $150 \pm 1.36$ & $0.63 \pm 0.15$ & $99.66 \pm 2.33$ \\
\hline F8 & $4.33 \pm 1.75$ & $2.59 \pm 0.15$ & $151 \pm 1.45$ & $0.49 \pm 0.16$ & $99.63 \pm 1.83$ \\
\hline F9 & $4.45 \pm 1.59$ & $2.59 \pm 0.14$ & $150 \pm 1.63$ & $0.47 \pm 0.15$ & $99.75 \pm 1.63$ \\
\hline
\end{tabular}

\section{Ex-vivo mucoadhesive residence time:}

The ex vivo mucoadhesive properties of the tablets were determined using porcine buccal mucosa. As the concentration of polymer increased, the retention time increased. This test reflects the adhesive capacity of polymers used in formulations. The results revealed that combination of Carbopol, with HPMCK4M, Eudragit and $\mathrm{Na}$ CMC containing formulations showed more than six hours bioadhesion time. Optimized formulation i.e., F8 showed maximum retention time than other formulations (Table 4).

\section{Swelling studies:}

The swelling index examination indicated that the rate of swelling becomes directly proportional to the used polymer content. The swelling index was calculated concerning time. The swelling index demonstrates the relative moisture absorption capacities of polymers and whether or not the formulations maintain their integrity after moisture absorption. The swelling values of the tablets showed growth in swelling value with an increase in polymer content material. The results of the present formulation were tabulated in Table 5. Formulation F8 given maximum swelling and was found to be $76.88 \pm 1.46 \%$ within $8 \mathrm{~h}$. These results were correlated with earlier reported studies ${ }^{50}$.

Table 4: Mucoadhesive residence time of buccal tablets

\begin{tabular}{|c|c|}
\hline Formulation & Mucoadhesion time \\
\hline F1 & $6 \mathrm{~h} 10 \mathrm{~min}$ \\
\hline F2 & $7 \mathrm{~h} 10 \mathrm{~min}$ \\
\hline F3 & 7h $20 \mathrm{mr}$ \\
\hline F4 & $7 \mathrm{~h} 50 \mathrm{~min}$ \\
\hline F5 & $\geq 8 \mathrm{hr}$ \\
\hline F6 & $6 \mathrm{~h} 35 \mathrm{~min}$ \\
\hline F7 & $\geq 8 \mathrm{hr}$ \\
\hline F8 & $7 \mathrm{~h} 40 \mathrm{~min}$ \\
\hline F9 & \\
\hline
\end{tabular}


Table 5: Percent swelling index of CC buccal tablets (mean $\pm S D, n=3$ ).

\begin{tabular}{|c|c|c|c|c|c|c|c|c|c|}
\hline Formulati & F1 & F2 & F3 & F4 & F5 & F6 & F7 & F8 & F9 \\
\hline $1 \mathrm{hr}$ & $\begin{array}{c}19.63 \pm 1 \\
33\end{array}$ & $\begin{array}{c}19.36 \pm 1.5 \\
6\end{array}$ & $\begin{array}{c}20.33 \pm 1.9 \\
5\end{array}$ & $\begin{array}{c}20.79 \pm 14 \\
6\end{array}$ & $\begin{array}{c}15.33 \pm 1.8 \\
5\end{array}$ & $\begin{array}{c}18.69 \pm 1.9 \\
6\end{array}$ & $\begin{array}{c}23.54 \pm 1.4 \\
5\end{array}$ & $\begin{array}{c}20.65 \pm 1.7 \\
8\end{array}$ & $\begin{array}{c}16.33 \pm 1.6 \\
9\end{array}$ \\
\hline $2 \mathrm{hr}$ & $\begin{array}{c}36.55 \pm 1 \\
09\end{array}$ & $\begin{array}{c}36.58 \pm 1.6 \\
3\end{array}$ & $\begin{array}{c}38.33 \pm 1.6 \\
3\end{array}$ & $\begin{array}{c}34.93 \pm 15 \\
5\end{array}$ & $\begin{array}{c}25.66 \pm 1.9 \\
6\end{array}$ & $\begin{array}{c}28.94 \pm 1.7 \\
8\end{array}$ & $\begin{array}{c}38.58 \pm 1.5 \\
6\end{array}$ & $\begin{array}{c}36.26 \pm 1.6 \\
9\end{array}$ & $\begin{array}{c}32.55 \pm 1.5 \\
5\end{array}$ \\
\hline $3 \mathrm{hr}$ & $\begin{array}{c}42.63 \pm 1 \\
66\end{array}$ & $\begin{array}{c}44.66 \pm 1.6 \\
3\end{array}$ & $\begin{array}{c}46.62 \pm 1.4 \\
5\end{array}$ & $\begin{array}{c}42.65 \pm 1.8 \\
5\end{array}$ & $\begin{array}{c}33.45 \pm 1.5 \\
8\end{array}$ & $\begin{array}{c}36.58 \pm 18 \\
5\end{array}$ & $\begin{array}{c}48.26 \pm 1.5 \\
8\end{array}$ & $\begin{array}{c}45.58 \pm 1.2 \\
5\end{array}$ & $\begin{array}{c}40.69 \pm 1.8 \\
5\end{array}$ \\
\hline $4 \mathrm{hr}$ & $\begin{array}{c}47.95 \pm 1 \\
25\end{array}$ & $\begin{array}{c}52.25 \pm 1.5 \\
5\end{array}$ & $\begin{array}{c}55.55 \pm 1.5 \\
4\end{array}$ & $\begin{array}{c}51.47 \pm 14 \\
5\end{array}$ & $\begin{array}{c}42.66 \pm 1.5 \\
6\end{array}$ & $\begin{array}{c}46.59 \pm 1.9 \\
7\end{array}$ & $\begin{array}{c}60.36 \pm 1.6 \\
9\end{array}$ & $\begin{array}{c}55.69 \pm 1.3 \\
3\end{array}$ & $\begin{array}{c}51.25 \pm 1.5 \\
9\end{array}$ \\
\hline $6 \mathrm{hr}$ & $\begin{array}{c}58.25 \pm 1 \\
66\end{array}$ & $\begin{array}{c}61.96 \pm 1.6 \\
9\end{array}$ & $\begin{array}{c}64.56 \pm 1.6 \\
3\end{array}$ & $\begin{array}{c}60.77 \pm 16 \\
9\end{array}$ & $\begin{array}{c}56.33 \pm 1.3 \\
3\end{array}$ & $\begin{array}{c}59.89 \pm 1.9 \\
3\end{array}$ & $\begin{array}{c}66.58 \pm 1.5 \\
8\end{array}$ & $\begin{array}{c}63.59 \pm 1.5 \\
9\end{array}$ & $\begin{array}{c}60.89 \pm 1.6 \\
9\end{array}$ \\
\hline $8 \mathrm{hr}$ & $\begin{array}{c}63.25 \pm 1 \\
45\end{array}$ & $\begin{array}{c}69.54 \pm 1.5 \\
6\end{array}$ & $\begin{array}{c}73.56 \pm 1.6 \\
9\end{array}$ & $\begin{array}{c}64.86 \pm 1.5 \\
8\end{array}$ & $\begin{array}{c}62.55 \pm 16 \\
6\end{array}$ & $\begin{array}{c}68.99 \pm 1.5 \\
5\end{array}$ & $\begin{array}{c}75.69 \pm 1.8 \\
9\end{array}$ & $\begin{array}{c}76.88 \pm 1.4 \\
6\end{array}$ & $\begin{array}{c}71.78 \pm 1.5 \\
7\end{array}$ \\
\hline
\end{tabular}

\section{In-vitro drug release studies:}

The In-vitro drug release study has been done for various formulations (F1-F9) in phosphate buffer $\mathrm{pH}$ 6.8. The different ratios of polymers were used in the prepared buccal tablets. Among the nine batches, formulation F1 - F3 was developed carbopol with HPMC $\mathrm{K}_{4} \mathrm{M}$ polymer in the ratio of 1:2 to 1: 4. Carbopol used as primary polymer in all formulations based on the excellent swelling and adherent characteristics to the mucosal surface. As the concentration of secondary polymer increased, the drug release was retarded. The F1-F3 formulation released $100.55 \pm 3.33 \%$, $97.46 \pm 2.91 \%$, and $93.66 \pm 3.63 \%$ drug release drug during 8 $\mathrm{h}$, respectively. This might be due to the swelling of the polymer and diffusion takes place. The results are presented in Figures 1, 2, and 3.
Similarly, in the case of F4-F6 formulations, developed with carbopol and Eudragit RLPO showed 100.45 $\pm 3.12 \%$, $96.65 \pm 4.16 \%$, and $86.59 \pm 3.33 \% \%$ release respectively during 8h. From F7-F9 formulations showed $99.45 \pm 3.93 \%$, $102.37 \pm 3.81 \%$, and $94.95 \pm 3.25 \%$ release respectively, the formulations F3, F6, and F9 prolonged the drug release could be appeared up to $8 \mathrm{~h}$ with a controlled manner. Among all F8 denoted optimized based on controlled drug release and highest drug released at $8 \mathrm{~h}$. These results were in accordance with earlier studies ${ }^{51}$. The swelling study, bioadhesion time, and ex-vivo drug permeation studies also appeared good results hence, F8 was considered as the best formulation.

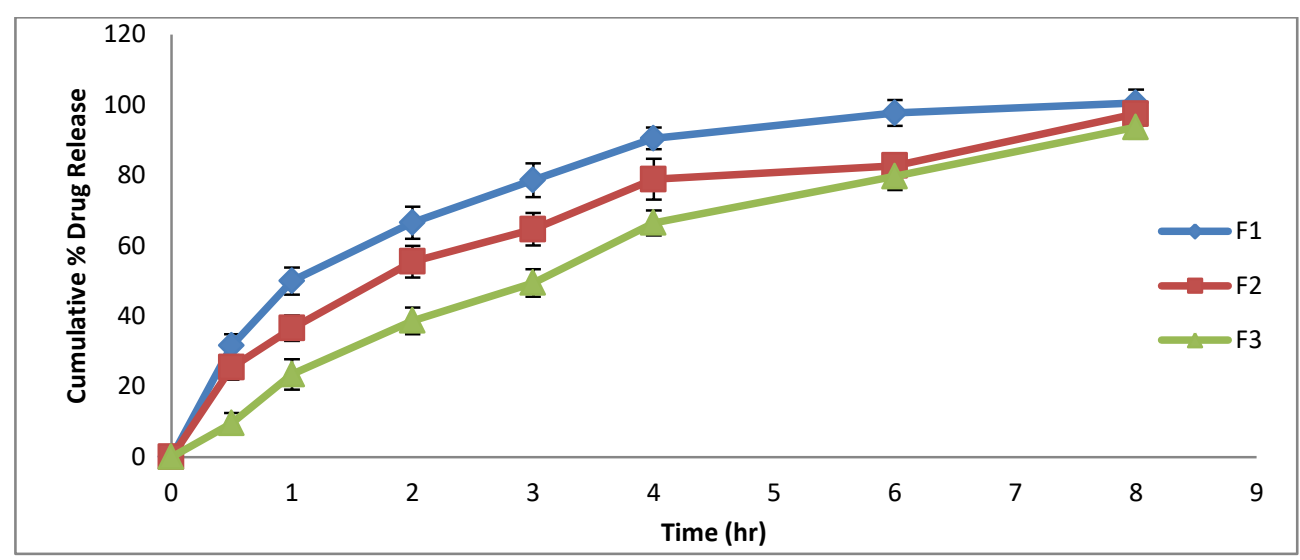

Figure 1: In vitro release profiles of CC from CC buccal tablets (F1-F3) (Mean \pm SD, $n=3$ ).

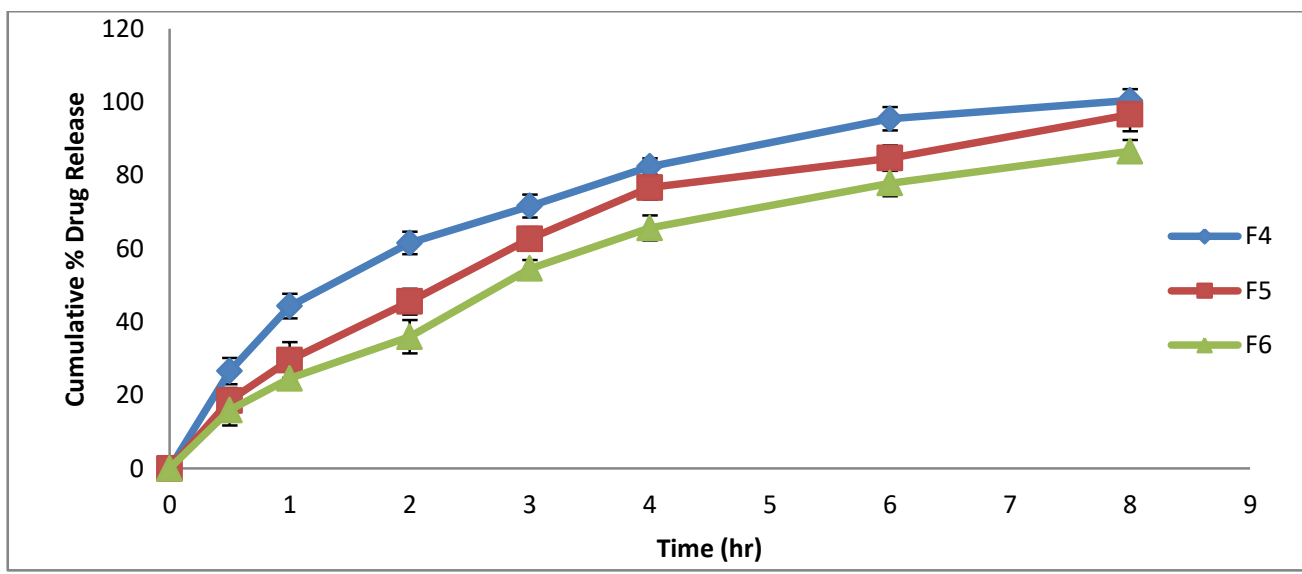

Figure 2: In vitro release profiles of CC from CC buccal tablets (F4-F6) (Mean \pm SD, $n=3$ ). 


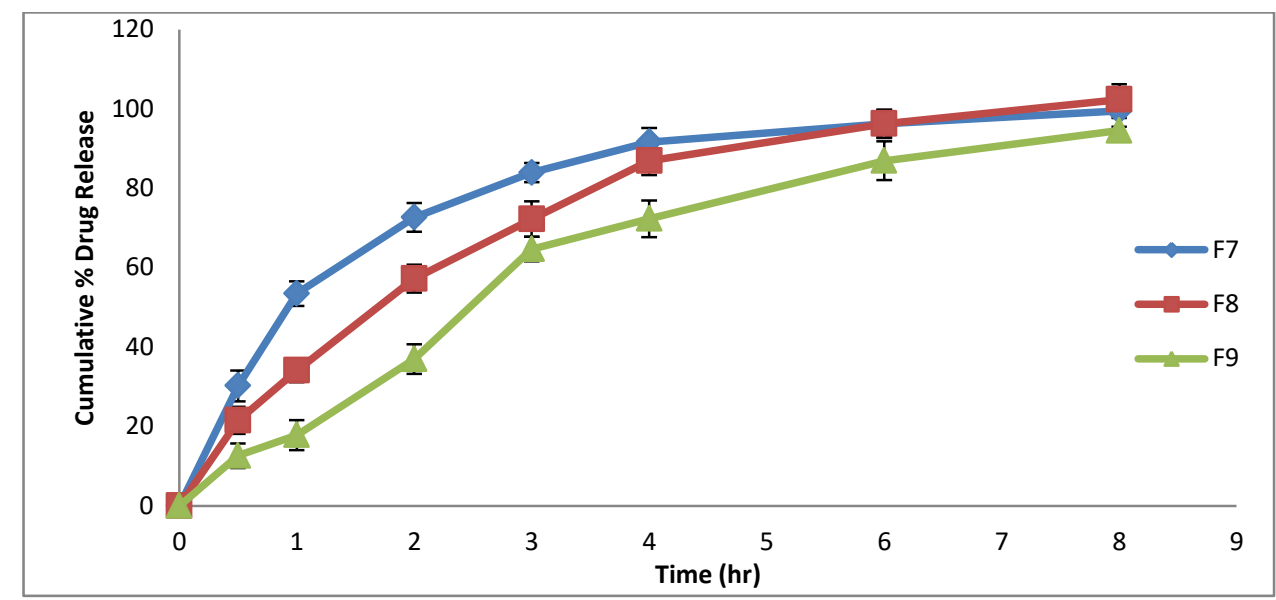

Figure 3: In vitro release profiles of CC from CC buccal tablets (F7-F9) (Mean \pm SD, n=3).

\section{Drug release kinetic mechanism:}

The release mechanism and kinetics of CC formulations were to fit into mathematical models and the higher $\mathrm{R}^{2}$ values for Zero-order and Higuchi suggest that the drug release follows zero-order kinetics with diffusion mechanism. Similarly, previously reported formulations followed this type of trend in release ${ }^{52}$.

\section{Ex vivo permeation studies:}

Ex vivo permeation of $\mathrm{F} 8$ formulation was conducted through porcine buccal mucosa by using Franz diffusion apparatus. The cumulative amount of drug permeated was found to be
$82.98 \pm 2.63 \%$ in $8 \mathrm{~h}$. Before the study, the permeation of pure CC drug solution was also studied and was found to be $65.66 \%$ in $8 \mathrm{~h}^{53-55}$

\section{FTIR compatibility studies:}

The FTIR spectra of significant peaks detected in the spectrum of pure drug optimized F8 formulation (Figure 4) and were described as follows: The spectrum of pure CC presented characteristic peaks at $3651.63 \mathrm{~cm}^{-1}$. The pure drug peaks were unchanged in the spectrum of drug with polymers, which proves that there is no interaction between drug and excipients. So the drug is compatible with excipients 56,13 .

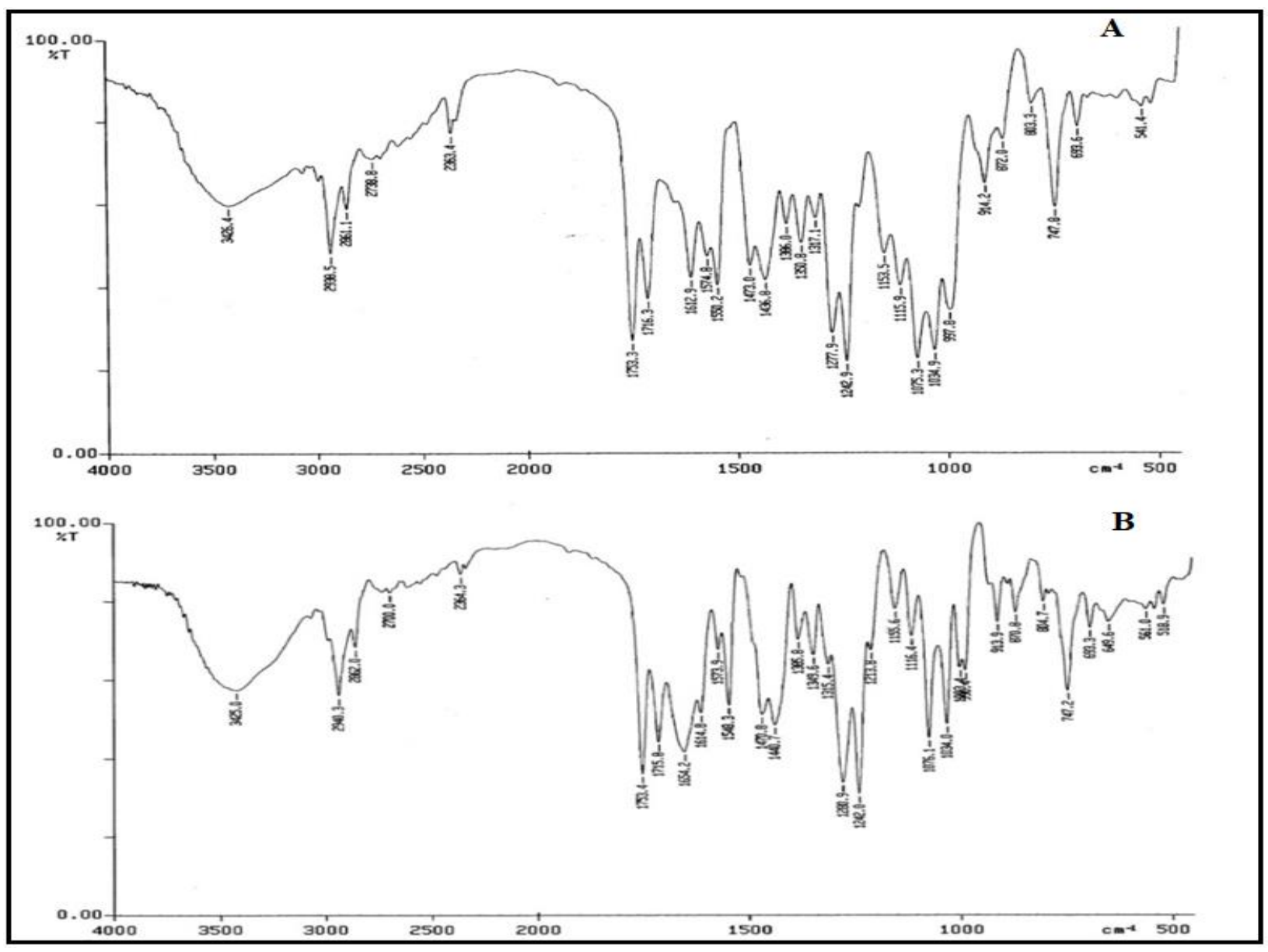

Figure 4: FTIR spectrum of pure drug (A) and optimized formulation (B) 


\section{CONCLUSION:}

The present investigation was designed to develop the mucoadhesive buccal tablets of CC with a controlled effect that avoids the first-pass metabolism and improves oral bioavailability. All the prepared tablets were within the acceptable Pharmacopoeial limits for evaluation parameters. The optimized formulation F8 was best in terms of drug release, mucoadhesive permeation across the mucosal membrane. Hence, it can be concluded that the formulations of CC mucoadhesive buccal tablets are promising as they controlled drug delivery, improve bioavailability, and maybe a good candidate for buccal delivery. Further, in-vivo research in animal fashions is required to prove the bioavailability performance of the formulation.

\section{ACKNOWLEDGEMENTS:}

The authors are thankful to management of Vaagdevi colleges and Principal, Dr. G. Kamal Yadav, Vaagdevi Pharmacy College, Bollikunta, Warangal for providing the necessary facilities to carry out the research work.

\section{REFERENCES:}

1. Zhang H, Zhang J, Streisand JB. Oral mucosal drug delivery. Clinical pharmacokinetics. 2002 Aug 1; 41(9):661-80.

2. Laffleur F, Bernkop-Schnürch A. Strategies for improving mucosal drug delivery. Nanomedicine. 2013 Dec; 8(12):2061-75.

3. Doodipala R. A review of novel formulation strategies to enhance oral delivery of zaleplon. J Bioequvi avail. 2016; 8(5): 211-213.

4. Chinna Reddy Palem, Ramesh Gannu, Narender D, Vamshi Vishnu Yamsani, and Madhusudan Rao Yamsani. Transmucosal Delivery of Domperidone from Bilayered Buccal Patches: In Vitro, Ex Vivo and In Vivo Characterization. Arch Pharm Res. 2011; 34(10):1701-1710.

5. Narendar D, Thirupathi G. Neuroprotective effect of ropinirole loaded lipid nanoparticles hydrogel for Parkinson's disease: preparation, in vitro, ex vivo, pharmacokinetic and pharmacodynamic evaluation. Pharmaceutics, 2020; 12(5):448.

6. Dudhipala N, Narala A, Bomma R. Recent Updates in the Formulation Strategies to Enhance the Bioavailability of Drugs Administered via Intranasal Route. J Bioequiv Availab 8: 204207. doi: $10.4172 / \mathrm{jbb}$.

7. Banala N, Peddapalli H, Dudhipala N, Chinnala KM. Transmucosal Delivery of Duloxetine Hydrochloride for Prolonged Release: Preparation, in vitro, ex vivo Characterization and in vitro-ex vivo Correlation. International Journal of Pharmaceutical Sciences and Nanotechnology. 2018 Sep 30; 11(5):4249-58.

8. Donthi MR, Dudipala N, Komalla DR, Suram D, Banala N. Design and evaluation of floating multi unit mini tablets (mumts) muco adhesive drug delivery system of famotidine to treat upper gastro intestinal ulcers. Journal of Pharmacovigilance. 2015 Oct 12.

9. Chopparapu C, Palem CR, Yamsani MR. Development of Promethazine mucoadhesive tablets for buccal delivery: in-vitro, ex-vivo and in-vivo characterization. American Jr PharmTech Res. 2012; 2(1):1697-705.

10. Chinna Reddy Palem, Narendar D, Sunil Kumar Battu, Satyanarayana Goda, and Madhusudan Rao Yamsani. Combined dosage form of pioglitazone and felodipine as mucoadhesive pellets via hot melt extrusion for improved buccal delivery with application of quality by design approach. J Drug Del Sci Tech. 2015; 30:209-219.

11. Zhang Z, Gao F, Bu H, Xiao J, Li Y. Solid lipid nanoparticles loading candesartan cilexetil enhance oral bioavailability: in vitro characteristics and absorption mechanism in rats. Nanomedicine: Nanotechnology, Biology and Medicine. 2012 Jul 1; 8(5):740-7.

12. Easthope SE, Jarvis B. Candesartan cilexetil. Drugs. 2002 Jun 1; 62(8):1253-87.

13. Gurunath S, Shailesh S, Narender D, Sandhya G, Baswaraj KN. Strongly enhanced dissolution rate of candesartan cilexetil solid dispersion tablets by incorporation of superdisintegrants. J. Pharm. Res. 2011; 4:4190-4.
14. Samanthula KS, Satla SR, Bairi AG. Development, In-Vitro and ExVivo Evaluation of Muco-adhesive Buccal patches of Candesartan cilexetil. Research Journal of Pharmacy and Technology. 2019; 12(6):3038-44.

15. Donthi MR, Dudhipala NR, Komalla DR, Suram D, Banala N. Preparation and evaluation of fixed combination of ketoprofen enteric coated and famotidine floating mini tablets by single unit encapsulation system. Journal of Bioequivalence \& Bioavailability. 2015; 7(6):279.

16. Swamy SK, Reddy LN, Goud BA. Development and in vitro evaluation of bioadhesive buccal tablets of hydralazine hydrochloride. Int. J. Pharm. Educ. Res. 2014; 1:8-16.

17. Reddy AB, Reddy ND. Development of multiple-unit floating drug delivery system of clarithromycin: formulation, in vitro dissolution by modified dissolution apparatus, in vivo radiographic studies in human volunteers. Drug research. 2017 Jul; 67(07):412-8.

18. Reddy, N.D., Chinna R. P., Sunil, R., \& \& Madhusudan, R. Y Development of floating matrix tablets of Ofloxacin and Ornidazole in combined dosage form: in vitro and in vivo evaluation in healthy human volunteers. Int J Drug Deli, 2012; 4:462-469.

19. Ramana MV, Nagada C, Himaja M. Design and evaluation of mucoadhesive buccal drug delivery systems containing metoprolol tartrate. Indian Journal of Pharmaceutical Sciences. 2007; 69(4): 515-518.

20. Narendar D, K. Someshwar, N. Arjun and Y. Madhusudan Rao. Quality by design approach for development and optimization of Quetiapine Fumarate effervescent floating matrix tablets for improved oral delivery. J Pharm Investigation., 2016; 46(3):253263.

21. Rajitha R, Narendar D, Arjun N, Mahipal D and Nagaraj B. Colon delivery of naproxen: preparation, characterization and in vivo evaluation. IJPSN, 2016; 9(3):1-10.

22. Alekya T, Narendar D, Mahipal D, Arjun N, Nagaraj B. Design and evaluation of chronomodulated drug delivery of tramadol hydrochloride. Drug research. 2018 Mar; 68(03):174-80.

23. Gowthamarajan K, Jawahar N, Wake P, Jain K, Sood S. Development of buccal tablets for curcumin using Anacardium occidentale gum. Carbohydrate Polymers. 2012 May 16; 88(4):1177-83.

24. Arjun N, Narendar D, Sunitha K, Harika K, Madhusudan Rao Y and Nagaraj B. Development, evaluation and influence of formulation and process variables on in vitro performance of oral elementary osmotic device of atenolol. Int J Pharm Invest, 2016; 6(4):1-9.

25. Çelik B. Risperidone mucoadhesive buccal tablets: formulation design, optimization and evaluation. Drug Design, Development and Therapy. 2017; 11:3355.

26. Narendar D, Arjun N, Karthik Yadav J and Ramesh Bomma. Amoxycillin Trihydrate Floating-Bioadhesive Drug Delivery System for Eradication of Helicobacter pylori: Preparation, In Vitro and Ex Vivo Evaluation. J bioequ avail. 2016; 8(3):118-124.

27. Jain AC, Aungst BJ, Adeyeye MC. Development and in vivo evaluation of buccal tablets prepared using danazolsulfobutylether $7 \beta$-cyclodextrin (SBE 7) complexes. Journal of pharmaceutical sciences. 2002 Jul; 91(7):1659-68.

28. Chinna Reddy Palem, Narendar D, Sunil Kumar Battu, Michael A Repka and Madhusudan Rao Yamsani. Development, Optimization and in vivo Characterization of Domperidone Controlled Release Hot Melt Extruded Films for Buccal Delivery. Drug Dev Ind Pharm, 2016; 42(3):473-484.

29. El-Nahas AE, Allam AN, El-Kamel AH. Mucoadhesive buccal tablets containing silymarin Eudragit-loaded nanoparticles: formulation, characterisation and ex vivo permeation. Journal of Microencapsulation. 2017 Jul 4; 34(5):463-74.

30. Narendar D, Riyaz PMD, Ahmed AY, Nagaraj B. Effect of lipid and edge activator concentration on development of Aceclofenac loaded transfersomes gel for transdermal application: in vitro and ex vivo skin permeation. Dru Dev Ind Pharm. 2020; 46(8):1334-1344.

31. Dudhipala, Narendar, Ahmed Adel Ali Youssef, and Nagaraj Banala. Colloidal lipid nanodispersion enriched hydrogel of antifungal agent for management of fungal infections: comparative in-vitro, ex-vivo and in-vivo evaluation for oral and topical application. Chemistry and Physics of Lipids (2020): 104981. 
32. Ahmed AAY, Narendar D, Mujumdar S. Ciprofloxacin Loaded Nanostructured Lipid Carriers Incorporated into In-Situ Gels to Improve Management of Bacterial Endophthalmitis. Pharmaceutics, 2020; 12(6):572.

33. Narendar D and Kishan V. Candesartan cilexetil nanoparticles for improved oral bioavailability. Ther deli, 2017; 8(2):79-88.

34. Geçer A, Yıldız N, Çalımlı A, Turan B. Trimethyl chitosan nanoparticles enhances dissolution of the poorly water soluble drug candesartan-cilexetil. Macromolecular research. 2010 Oct 1; 18(10):986-91.

35. Dudhipala N, Veerabrahma K. Candesartan cilexetil loaded solid lipid nanoparticles for oral delivery: characterization, pharmacokinetic and pharmacodynamic evaluation. Drug delivery. 2016 Feb 12; 23(2):395-404.

36. Ettireddy S, Dudhipala N. Influence of $\beta$-Cyclodextrin and Hydroxypropyl- $\beta$-Cyclodextrin on Enhancement of Solubility and Dissolution of Isradipine. Int J Pharma Sci and Nanotech. 2017; 10(3):3752-7.

37. Palem CR, Reddy ND, Satyanarayana G, Varsha BP. Development and optimization of Atorvastatin calciumcyclodextrin inclusion complexed oral disintegrating tablets for enhancement of solubility, dissolution, pharmacokinetic and pharmacodynamic activity by central composite design. Int Pharm Sci Nanotech 2016; 9(2): 1-11.

38. Butreddy A, Narendar D. Enhancement of solubility and dissolution rate of trandolapril sustained release matrix tablets by liquisolid compact approach. Asian J Pharm 2015; 9 (4): 290297.

39. Dudipala R, Palem CR, Reddy S, Rao YM. Pharaceutical development and clinical pharmacokinetic evaluation of gastroretentive floating matrix tablets of levofloxacin. Int $J$ Pharma Sci and Nanotech, 2011; 4(3):1461-1467.

40. Veerabrahma K. Development of olmesartan medoxomil lipidbased nanoparticles and nanosuspension: preparation, characterization and comparative pharmacokinetic evaluation. Artificial cells, nanomedicine, and biotechnology. 2018 Feb; 46(1):126.

41. Kishan V, Sandeep V, Narendar D, Arjun N. Lacidipine loaded solid lipid nanoparticles for oral delivery: preparation, characterization and in vivo evaluation. International Journal of Pharmaceutical Sciences and Nanotechnology. 2016 Nov 30; 9(6):3524-30.

42. Narendar D, Veerabrahma K. Improved anti-hyperlipidemic activity of Rosuvastatin Calcium via lipid nanoparticles: Pharmacokinetic and pharmacodynamic evaluation. European Journal of Pharmaceutics and Biopharmaceutics. 2017 Jan 1; 110:47-57.

43. Narendar D, Ahmed A AyA Amelioration of ketoconazole in lipid nanoparticles for enhanced antifungal activity and bioavailability through oral administration for management of fungal infections. Chemistry and Physics of Lipids 2020; 232:104953.
44. Banala, N, Tirumalesh C, Suram, D. Dudhipala, N. Zotepine loaded lipid nanoparticles for oral delivery: preparation, characterization, and in vivo pharmacokinetic studies. Fut J Pharm Sci, 2020; 6(1):37.

45. Vamshi Krishna M, Vijay Kumar B, Narendar Dudhipala. In-situ Intestinal Absorption and Pharmacokinetic Investigations of Carvedilol Loaded Supersaturated Self-Emulsifying Drug System. Pharm Nanotechnol. 2020 May 17. doi $10.2174 / 2211738508666200517121637$.

46. Pitta S, Dudhipala N, Narala A and Veerabrahma K. Development and evaluation of zolmitriptan transfersomes by Box-Behnken design for improved bioavailability by nasal delivery. Drug Dev Ind Pharm. 2018; 44(3):484-492.

47. Tirumalesh C, Suram, D.; Dudhipala, N.; Banala, N. Enhanced pharmacokinetic activity of Zotepine via nanostructured lipid carrier system in Wistar rats for oral application. Pharm. Nanotechnol. 2020; 8(2):158-160.

48. Karri V, Butreddy A, Narender R. Fabrication of Efavirenz Freeze Dried Nanocrystals: Formulation, Physicochemical Characterization, In Vitro and Ex Vivo Evaluation. Advanced Science, Engineering and Medicine. 2015; 7(5):385-392.

49. Nagaraj K, D. Narendar and V. Kishan. Development of olmesartan medoxomil optimized nanosuspension using the Box-Behnken design to improve oral bioavailability. Drug Dev Ind Pharm, 2017; 43(7):1186-1196.

50. Esim 0, Savaser A, Ozkan CK, Bayrak Z, Tas C, Ozkan Y. Effect of polymer type on characteristics of buccal tablets using factorial design. Saudi Pharmaceutical Journal. 2018 Jan 1; 26(1):53-63.

51. Mahipalreddy D, Narendar D, Devendhar K, Dinesh S, Kiran S, Nagaraj B. Preparation and evaluation of ketoprofen enteric coated mini tablets for prevention of chronic inflammatory disease. J Pharm Drug Deliv Res. 2015; 4(2).

52. Boyapally H, Nukala RK, Bhujbal P, Douroumis D. Controlled release from directly compressible theophylline buccal tablets. Colloids and Surfaces B: Biointerfaces. 2010 Jun 1; 77(2):227-33.

53. Koradia H, Chaudhari K. Formulation of unidirectional buccal tablet of Mirtazapine: an in vitro and ex vivo evaluation. Journal of Drug Delivery Science and Technology. 2018 Feb 1; 43:23342.

54. Shruthi K, Narendar D, Arjun N, Kishan V. Development and Antimicrobial Evaluation of Binary Ethosomal Topical Gel of Terbinafine Hydrochloride for the Treatment of Onychomycosis. Int. J. Pharm. Sci. Nanotechnol. 2018; 11:3998-4005.

55. Nagaraj B, Anusha K, Narendar D, Sushma P. Formulation and evaluation of microemulsion-based transdermal delivery of duloxetine hydrochloride. International Journal of Pharmaceutical Sciences and Nanotechnology. 2020 Jan 31; 13(1):4773-82.

56. Shivanand K, Raju SA, Nizamuddin S, Jayakar B. In vivo bioavailability studies of sumatriptan succinate buccal tablets. DARU: Journal of Faculty of Pharmacy, Tehran University of Medical Sciences. 2011; 19(3):224. 